\title{
Efficient and improved synthesis of Telmisartan
}

\author{
A. Sanjeev Kumar, Samir Ghosh and G. N. Mehta*
}

\author{
Full Research Paper \\ Address: \\ Applied Chemistry Department, Sardar Vallabhbhai National Institute \\ of Technology, Surat-395 007, India \\ Email: \\ G. N. Mehta* - drgnmehta@rediffmail.com \\ * Corresponding author \\ Keywords: \\ antihypertensive drug; oxazoline hydrolysis; Suzuki coupling; \\ Telmisartan
}

Beilstein Journal of Organic Chemistry 2010, 6, No. 25.
doi:10.3762/bjoc. 6.25

Received: 10 January 2010

Accepted: 25 February 2010

Published: 11 March 2010

Associate Editor: J. A. Porco Jr.

(C) 2010 Kumar et al; licensee Beilstein-Institut.

License and terms: see end of document.

\begin{abstract}
An efficient synthesis of the angiotensin II receptor antagonist Telmisartan (1) is presented involving a cross coupling of 4-formylphenylboronic acid 10 with 2-(2-bromophenyl)-4,4-dimethyl-2-oxazoline (11) as the key step (90\% yield). The benzimidazole moiety $\mathbf{1 5}$ was constructed regioselectively via a reductive amination-condensation sequence, replacing the alkylation of the preformed benzimidazole step in the previously published route. This methodology overcomes many of drawbacks associated with previously reported syntheses.
\end{abstract}

\section{Introduction}

Telmisartan (1) is an angiotensin II receptor antagonist useful in the treatment of hypertension, heart diseases, heart attack, and bladder diseases [1-3]. Telmisartan is currently available in the market as an antihypertensive drug [4] under the brand name of Micardis ${ }^{\circledR}$.

Essential hypertension is a major risk factor in cardiovascular diseases and is responsible for one-third of global deaths. Most antihypertensive drugs interact with the renin-angiotensin system (RAS), which is the central regulator of blood pressure and electrolyte homeostasis. Renin transforms angiotensinogen into the decapeptide angiotensin I, which is converted by the angiotensin conversion enzyme (ACE) into the octapeptide angiotensin II. The latter binds to its angiotensin receptor $\left(\mathrm{AT}_{1}\right)$ and, thereby, becomes a powerful vasoconstrictor. In the early 1990 s, Merck introduced the non-peptidic orally active angiotensin II receptor antagonist losartan (Lozaar) as the first member of a new class of antihypertensive drugs called sartans, all of which contain a characteristic ortho functionalized biaryl moiety. Telmisartan (1, Boehringer Ingelheim, Micardis ${ }^{\circledR}$ ) (Figure 1) is an important member of this class of top-selling drugs because it has the strongest binding affinity to the $\mathrm{AT}_{1}$ receptor, an excellent bioavailability, and a once-per-day dosage.

The first total synthesis of Telmisartan as introduced by Ries et al. (Scheme 1) starts with the acylation of 4-amino-3-methylbenzoic acid methyl ester (2) with butyryl chloride, followed by nitration, reduction of the nitro group, and subsequent cyclization of the resulting amine to the benzimidazole derivative $\mathbf{3}$. After saponification, the free carboxyl group is condensed with $\mathrm{N}$-methyl-1,2-phenylenediamine to afford the bis-benzimida- 
<smiles>CCCc1nc2c(C)cc(-c3nc4ccccc4n3C)cc2n1Cc1ccc(-c2ccccc2C(=O)O)cc1</smiles>

1

Figure 1: The angiotensin II receptor antagonist Telmisartan.

zole 4, which is then alkylated with the $4^{\prime}$-(bromomethyl)-2biphenylcarboxylic acid tert-butyl ester (8) to give, after hydrolysis of the ester group, Telmisartan (1) in $21 \%$ overall yield and with eight steps as the longest sequence [5].

Several improvements to the above reaction sequence have been reported, e.g., the use of $\mathrm{KOH}$ instead of potassium tert- butoxide in the penultimate step and the use of methanolic $\mathrm{HCl}$ solution instead of trifluoroacetic acid in the final step [6]. However, the main shortcomings of the synthesis remained, namely, the unsatisfactory regioselectivity in the alkylation of $\mathbf{8}$ with $\mathbf{4}$ and the intricate synthesis of the biaryl intermediate 7. In the original protocol, the latter was synthesized via an Ullmann coupling of the aryl iodides 5 and $\mathbf{6}$ using 5 equiv of copper [7]. Modern syntheses of $\mathbf{7}$ involve cross-couplings of sensitive aryl magnesium [8], zinc [9], or boron [10,11] compounds with alkyl 2-halobenzoates. Since the commercialization of Telmisartan, 7 has become readily available at low cost, so that most subsequent published procedures start from this compound.

In designing an alternative synthesis of Telmisartan our goal was to minimize the use of expensive and hazardous metals, circumvent the bromination step, and increase the overall efficiency of the synthesis. This was accomplished by reversing the order of the major bond disconnections. We realized biaryl synthesis and reductive amination are the key steps, and have the potential to overcome both of these weaknesses.<smiles>CCCc1nc2c(C)cc(-c3nc4ccccc4n3C)cc2[nH]1</smiles><smiles>Cc1ccc(-c2ccccc2C(=O)OC(C)(C)C)cc1</smiles><smiles>CCCc1nc2c(C)cc(-c3nc4ccccc4n3C)cc2n1Cc1ccc(-c2ccccc2C(=O)O)cc1</smiles><smiles>CCCc1nc2c(C)cc(-c3nc4ccccc4n3C)cc2n1Cc1ccc(-c2ccccc2C(=O)OC(C)(C)C)cc1</smiles>

Scheme 1: First literature synthesis of Telmisartan (a) ${ }^{n} \mathrm{PrCOCl}, \mathrm{C}_{6} \mathrm{H}_{5} \mathrm{Cl}, 100{ }^{\circ} \mathrm{C}$ (b) $\mathrm{HNO}_{3} / \mathrm{H}_{2} \mathrm{SO}_{4}, 0^{\circ} \mathrm{C}$ (c) $\mathrm{Pd} / \mathrm{C}, 5$ bar, $\mathrm{H}_{2}, \mathrm{MeOH}$ (d) $\mathrm{AcOH}, 120^{\circ} \mathrm{C}$, yield: $78 \%$ (e) $\mathrm{NaOH}, \mathrm{MeOH} / \mathrm{H}_{2} \mathrm{O}, 100^{\circ} \mathrm{C}$ (f) $2-\mathrm{MeNH}^{\circ} \mathrm{C}_{6} \mathrm{H}_{4}-\mathrm{NH}_{2}$, PPA, $150^{\circ} \mathrm{C}$, yield: $64 \%$ (g) ${ }^{t} \mathrm{BuOK}$, DMSO, RT (h) TFA, DCM, RT, yield: $42 \%$ (i) $\mathrm{Cu}$

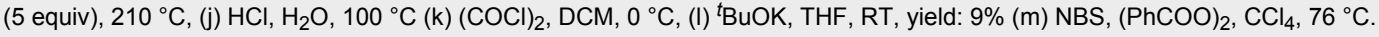




\section{Results and Discussion}

We identified 4-formylphenylboronic acid (10) and 2-(2bromophenyl)-4,4-dimethyl-2-oxazoline (11) [12] as the ideal starting materials for the preparation of the key biaryl intermediate. Thus, Suzuki coupling of 2-(2-bromophenyl)-4,4dimethyl-2-oxazoline with 4-formylphenylboronic acid in presence of aqueous sodium carbonate and tetrakis(triphenylphosphine)palladium(0) in THF solvent gave 2'-(4,4-dimethyl-4,5dihydro-1,3-oxazol-2-yl)biphenyl-4-carbaldehyde (12) in over $90 \%$ yield (Scheme 2 ).<smiles>CC1(C)COC(c2ccccc2-c2ccc(C=O)cc2)=N1</smiles>

Scheme 2: (a) $\mathrm{Pd}\left(\mathrm{PPh}_{3}\right)_{4}$, aq $\mathrm{Na}_{2} \mathrm{CO}_{3}$, THF, $12.0 \mathrm{~h}, 90 \%$.
The reductive amination of the biaryl aldehyde 12 with amine 13 (prepared by the literature procedure [13]) was carried out in the presence of $p$-toluenesulfonic acid in toluene and followed by hydrogenation in methyl alcohol. The resulting amine 14 was not isolated but cyclized in situ to the $n$-propyl benzimidazole 15 in $80 \%$ yield in refluxing glacial acetic acid. Finally, cleavage of the oxazoline moiety in $\mathbf{1 5}$ by acid afforded Telmisartan (1) (Scheme 3).

\section{Conclusion}

In conclusion, a concise and selective synthesis of the antihypertensive drug Telmisartan has been developed, featuring a Suzuki cross-coupling for the construction of the biaryl moiety and a regiospecific reductive amination-condensation sequence for the synthesis of the central benzimidazole.

\section{Experimental}

All solvents and reagents were purchased from the commercial suppliers and used without further purification. All non-aqueous reactions were performed in dry glassware under an atmosphere of dry nitrogen. Organic solutions were concentrated under reduced pressure. Thin layer chromatography was performed on Merck precoated Silica-gel $60 \mathrm{~F}_{254}$ plates. ${ }^{1} \mathrm{H}$ and<smiles>CCCC(=O)Nc1c(C)cc(-c2nc3ccccc3n2C)cc1N</smiles>

13<smiles>CC1(C)COC(c2ccccc2-c2ccc(C=O)cc2)=N1</smiles>

12<smiles>CCCC(=O)Nc1c(C)cc(-c2nc3ccccc3n2C)cc1NCc1ccc(-c2ccccc2C2=NC(C)(C)CO2)cc1</smiles><smiles>CCCc1nc2c(C)cc(-c3nc4ccccc4n3C)cc2n1Cc1ccc(-c2ccccc2C2=NC(C)(C)CO2)cc1</smiles>

d<smiles>CCCc1nc2c(C)cc(-c3nc4ccccc4n3C)cc2n1Cc1ccc(-c2ccccc2C(=O)O)cc1</smiles> 
${ }^{13} \mathrm{C}$ NMR spectra were recorded in DMSO- $d_{6}$ and $\mathrm{CDCl}_{3}$ using $400 \mathrm{MHz}$, on a Varian Gemini $400 \mathrm{MHz}$ FT NMR spectrometer. The chemical shifts were reported in $\delta$ ppm relative to TMS (tetramethylsilane). The IR spectra were recorded in the solid state as $\mathrm{KBr}$ dispersion using Perkin Elmer FT-IR spectrophotometer. The mass spectra were recorded on Shimadzu LCMS-QP 800 LC-MS and AB-4000 Q-trap LC-MS/MS Melting points were obtained by using the open capillary method and are uncorrected.

2'-(4,4-dimethyl-4,5-dihydro-1,3-oxazol-2-yl)biphenyl-4carbaldehyde (12): To a mixture of 4-formylphenylboronic acid (10) (5.0 g, $0.032 \mathrm{~mol})$ and 2-(2-bromophenyl)-4,4dimethyl-2-oxazoline (11) $(10.1 \mathrm{~g}, 0.039 \mathrm{~mol})$ in tetrahydrofuran $(50.0 \mathrm{~mL}), 2 \mathrm{M}$ aqueous sodium carbonate solution $(20.0 \mathrm{~mL})$ was added at room temperature. The resulting biphasic solution was degassed with nitrogen gas for $20 \mathrm{~min}$. Tetrakis(triphenylphosphine)palladium $(0)(0.25 \mathrm{~g})$ was added and heated to reflux $\left(64{ }^{\circ} \mathrm{C}\right)$. The reaction mixture was maintained under reflux for $12 \mathrm{~h}$. After completion of the reaction, the reaction mixture was cooled to $26{ }^{\circ} \mathrm{C}$ and saturated ammonium chloride solution $(50 \mathrm{~mL})$ and ethyl acetate $(50 \mathrm{~mL})$ added. The organic layer was separated, washed twice with water $(50.0 \mathrm{~mL})$, dried over sodium sulfate and evaporated under vacuum. The residue was chromatographed on silica gel eluting with hexane/ethyl acetate 80:20 to give the title compound 12 as an oil $(8.0 \mathrm{~g}, 90 \%) ;{ }^{1} \mathrm{H}$ NMR (400 MHz, DMSO$\left.d_{6}\right)(\delta \mathrm{ppm}): 10.0(1 \mathrm{H}, \mathrm{s},-\mathrm{CHO}), 7.91(2 \mathrm{H}, \mathrm{d}, J=8.4 \mathrm{~Hz}, \mathrm{ArH})$, $7.73(1 \mathrm{H}, \mathrm{d}, J=8.4 \mathrm{~Hz}, \mathrm{ArH}), 7.48(2 \mathrm{H}, \mathrm{d}, J=7.8 \mathrm{~Hz}, \mathrm{ArH})$, 7.44-7.34 (2H, m, ArH), 7.30 (1H, m, $J=7.4 \mathrm{~Hz}, \mathrm{ArH}), 3.80$ $\left(2 \mathrm{H}, \mathrm{s},-\mathrm{CH}_{2}\right), 1.12\left(6 \mathrm{H}, \mathrm{s}, 2 \times-\mathrm{CH}_{3}\right) ;{ }^{13} \mathrm{C} \mathrm{NMR}(100 \mathrm{MHz}$, DMSO- $\left.d_{6}\right)(\delta \mathrm{ppm}) ; 28.0,68.0,78.9,128.0,128.5,129.5$, 129.6, 130.4, 130.5, 131.2, 135.3, 140.2, 147.0, 161.8, 193.2.; $\operatorname{MS}(\mathrm{m} / \mathrm{z}): 280\left[\mathrm{M}^{+}+1\right]$.

3'-\{[2'-(4,4-dimethyl-4,5-dihydro-1,3-oxazol-2-yl)biphenyl-4yl]methyl\}-1,7'-dimethyl-2'-propyl-1 $H, 3$ ' $H$-2,5'-bibenzimidazole (15): A mixture of $13(4.0 \mathrm{~g}, 0.01 \mathrm{~mol}), \mathbf{1 2}(3.5 \mathrm{~g}$, $0.01 \mathrm{~mol})$, and $p$-TsOH $(0.21 \mathrm{~g}, 0.001 \mathrm{~mol})$ was suspended in toluene $(40 \mathrm{~mL})$ under nitrogen, and the mixture refluxed for $16 \mathrm{~h}$ and then concentrated. The residue was diluted with methanol $(40 \mathrm{~mL})$ and transferred to a stainless steel autoclave. Palladium on charcoal $(10 \%, 1.0 \mathrm{~g})$ was added and the reaction mixture stirred under $\mathrm{H}_{2}$ pressure $(7 \mathrm{bar})$ for $24 \mathrm{~h}$ at $60{ }^{\circ} \mathrm{C}$. After cooling to room temperature and filtration, the filter cake was rinsed with ethyl acetate $(3 \times 50 \mathrm{~mL})$. The filtrate was washed with water, and the aqueous layer basified to $\mathrm{pH} 10$ with aqueous ammonia and extracted with ethyl acetate $(2 \times$ $50 \mathrm{~mL}$ ). The combined organic layers were dried over $\mathrm{MgSO}_{4}$ and concentrated. The crude amine $\mathbf{1 4}$ was diluted with glacial acetic acid $(40 \mathrm{~mL})$, the resulting solution refluxed for $2 \mathrm{~h}$ and then concentrated. Water $(150 \mathrm{~mL})$ was added to residue. The product was extracted twice with ethyl acetate $(2 \times 50 \mathrm{~mL})$ and evaporated under vacuum at $55{ }^{\circ} \mathrm{C}$. The residue was triturated with $n$-hexane ( $40 \mathrm{~mL}$ ) to yield a solid which was removed by filtration and dried at $50-55{ }^{\circ} \mathrm{C}$ for $3-4 \mathrm{~h}$ to afford 15 as a white crystalline powder (yield $5.7 \mathrm{~g}, 80 \%$ yield); melting point 191-193 ${ }^{\circ} \mathrm{C}$; IR $\left(\mathrm{KBr}, \mathrm{cm}^{-1}\right) 1630(\mathrm{C}=\mathrm{N})$; HRMS $\mathrm{m} / z$ calculated for $\mathrm{C}_{37} \mathrm{H}_{37} \mathrm{~N}_{5} \mathrm{O}-568.7225[\mathrm{M}+1]$, found - 568.7222; ${ }^{1} \mathrm{H}$ NMR (400 MHz, $\left.\mathrm{CDCl}_{3}\right)(\delta \mathrm{ppm}): 7.78(1 \mathrm{H}, \mathrm{d}, J=8.0 \mathrm{~Hz}$, ArH), $7.68(1 \mathrm{H}, \mathrm{m}, J=8.0 \mathrm{~Hz}, \mathrm{ArH}), 7.47-7.26(10 \mathrm{H}, \mathrm{m}, \mathrm{ArH})$, $7.07(2 \mathrm{H}, \mathrm{m}, J=8.0 \mathrm{~Hz}, \mathrm{ArH}), 5.45\left(2 \mathrm{H}, \mathrm{s},-\mathrm{CH}_{2}\right), 3.82(3 \mathrm{H}, \mathrm{s}$, $\left.-\mathrm{CH}_{3}\right), 3.58\left(2 \mathrm{H}, \mathrm{s},-\mathrm{CH}_{2}\right), 2.97\left(2 \mathrm{H}, \mathrm{t}, J=7.6 \mathrm{~Hz},-\mathrm{CH}_{2}\right), 2.74$ $\left(3 \mathrm{H}, \mathrm{s},-\mathrm{CH}_{3}\right), 1.92\left(2 \mathrm{H}, \mathrm{m}, J=7.6 \mathrm{~Hz},-\mathrm{CH}_{2}\right), 1.29(6 \mathrm{H}, \mathrm{s}, 2 \mathrm{x}$ $\left.-\mathrm{CH}_{3}\right), 1.04\left(3 \mathrm{H}, \mathrm{t}, J=7.6 \mathrm{~Hz},-\mathrm{CH}_{3}\right) ;{ }^{13} \mathrm{C} \mathrm{NMR}(100 \mathrm{MHz}$, $\left.\mathrm{CDCl}_{3}\right)(\delta \mathrm{ppm}): 13.9,16.7,21.6,27.6,29.6,31.6,46.9,67.2$, $79.0,108.8,109.2,119.3,122.1,122.2,123.5,123.6,125.6$, $127.0,127.2,128.8,129.1,129.7,129.9,130.2,134.4,134.8$, $136.4,140.6,140.8,142.6,142.8,154.2,156.2,163.1$.

4'-[(1,7'-dimethyl-2'-propyl-1 H,3' $H-2,5$ '-bibenzimidazol-3'yl)methyl]biphenyl -2-carboxylic acid (1): A mixture of 15 $(4.0 \mathrm{~g}, 0.007 \mathrm{~mol})$ and concentrated hydrochloric acid $(40 \mathrm{~mL})$ was heated at reflux $\left(100-110^{\circ} \mathrm{C}\right)$ for about $30 \mathrm{~h}$. The reaction mass was cooled to $0-5{ }^{\circ} \mathrm{C}$. Sodium hydroxide solution (20\%) was added until the $\mathrm{pH}$ of the reaction mixture was 9-10 and then stirred at room temperature for a further $2 \mathrm{~h}$. The resulting solid was removed by filtration and washed with water $(50 \mathrm{~mL})$. The wet cake was dissolved in a mixture of water $(60 \mathrm{~mL})$ and acetonitrile $(20 \mathrm{~mL})$ and then heated to $60-65^{\circ} \mathrm{C}$. The $\mathrm{pH}$ of the resulting clear solution was adjusted to $5.0-5.5$ with $5 \%$ acetic acid, and stirring continued for $2 \mathrm{~h}$. The precipitated solid was filtered and washed with water $(50 \mathrm{~mL})$. After drying at 70-75 ${ }^{\circ} \mathrm{C}$ for $4-5 \mathrm{~h}$ under a vacuum Telmisartan (1) was obtained as a white crystalline powder (yield $2.9 \mathrm{~g}, 80 \%$ ); melting point: $260-262{ }^{\circ} \mathrm{C}$ (lit [6] mp 260-262 ${ }^{\circ} \mathrm{C}$ ); IR ( $\mathrm{KBr}$, $\mathrm{cm}^{-1}$ ) 2300-3500 (broad), $1680(\mathrm{C}=\mathrm{O})$; HRMS $\mathrm{m} / z$ calculated for $\mathrm{C}_{33} \mathrm{H}_{30} \mathrm{~N}_{4} \mathrm{O}_{2}-515.6169[\mathrm{M}+1]$, found - 515.6192; ${ }^{1} \mathrm{H} \mathrm{NMR}\left(400 \mathrm{MHz}, \mathrm{CDCl}_{3}\right)(\delta \mathrm{ppm}): 12.8(1 \mathrm{H}, \mathrm{s},-\mathrm{COOH})$, $8.42(1 \mathrm{H}, \mathrm{d}, J=8.0 \mathrm{~Hz}, \mathrm{ArH}), 8.02(1 \mathrm{H}, \mathrm{d}, J=8.0 \mathrm{~Hz}, \mathrm{ArH})$, 7.50-7.26 (8H, m, ArH), $7.20(2 \mathrm{H}, \mathrm{d}, J=8.0 \mathrm{~Hz}, \mathrm{ArH}), 7.05$ $(1 \mathrm{H}, \mathrm{s}, \mathrm{ArH}), 6.96(1 \mathrm{H}, \mathrm{s}, \mathrm{ArH}), 5.42\left(2 \mathrm{H}, \mathrm{s},-\mathrm{CH}_{2}\right), 3.82(3 \mathrm{H}, \mathrm{s}$, $\left.-\mathrm{CH}_{3}\right), 2.97\left(2 \mathrm{H}, \mathrm{t}, J=7.6 \mathrm{~Hz},-\mathrm{CH}_{2}\right), 2.74\left(3 \mathrm{H}, \mathrm{s},-\mathrm{CH}_{3}\right), 1.92$ $\left(2 \mathrm{H}, \mathrm{m}, J=7.6 \mathrm{~Hz},-\mathrm{CH}_{2}\right), 1.04\left(3 \mathrm{H}, \mathrm{t}, J=7.6 \mathrm{~Hz},-\mathrm{CH}_{3}\right) ;{ }^{13} \mathrm{C}$ NMR (100 MHz, DMSO- $\left.d_{6}\right)(\delta \mathrm{ppm}): 13.5,16.7,20.6,27.6$, $32.7,47.1,51.7,112.0,112.7,114.7,118.6,125.3,125.7,125.8$, 127.0, 127.4, 128.6, 129.3, 130.4, 130.6, 131.5, 132.3, 133.1, $133.2,133.7,134.5,140.2,140.5,150.2,157.3,168.1$.

\section{Acknowledgements}

We are grateful to SVNIT, Surat and IICT, Hyderabad for supporting this work. 


\section{References}

1. Battershill, A. J.; Scott, L. J. Drugs 2006, 66, 51-83.

2. Hauel, N.; Narr, B.; Ries, U.; van Meel, J. C. A.; Wienen, W.; Entzeroth, M. Benzimidazoles useful as angiotensin-11 antagonists. U.S. Patent 5,591,762, Jan 7, 1997.

3. Wexler, R. R.; Greenlee, W. J.; Irvin, J. D.; Goldberg, M. R.; Prendergast, K.; Smith, R. D.; Timmermans, P. B. M. W. M. J. Med. Chem. 1996, 39, 625-656. doi:10.1021/jm9504722

4. http://www.rxlist.com/cgi/generic2/telmisartan.htm.

5. Ries, U. J.; Mihm, G.; Narr, B.; Hasselbach, K. M.; Wittneben, H.; Entzeroth, M.; van Meel, J. C. A.; Wienen, W.; Hauel, N. H. J. Med. Chem. 1993, 36, 4040-4051. doi:10.1021/jm00077a007

6. Reddy, K. S.; Srinivasan, N.; Reddy, C. R.; Kolla, N.; Anjaneyulu, Y.; Venkatraman, S.; Bhattacharya, A.; Mathad, V. T. Org. Process Res. Dev. 2007, 11, 81-85. doi:10.1021/op060200g

7. Carini, D. J.; Duncia, J. V.; Aldrich, P. E.; Chiu, A. T.; Johnson, A. L.; Pierce, M. E.; Price, W. A.; Santella, J. B., III; Wells, G. J.; Wexler, R. R.; Wong, P. C.; Yoo, S.-E.; Timmermans, P. B. W. M. J. Med. Chem. 1991, 34, 2525-2547. doi:10.1021/jm00112a031

8. Kohler, B.; Langer, M.; Mosandl, T. Catalyzed Coupling of Aryl magnesium halides and Bromo aryl carbon Acidic Compounds to the Production of Biphenyl Carboxlic Acid. Ger. Pat. Appl. DE19632643C1, Jan 22, 1998

9. Amatore, C.; Jutand, A.; Negri, S. J. Organomet. Chem. 1990, 390, 389-398. doi:10.1016/0022-328X(90)85107-A

10. Sharp, M. J.; Snieckus, V. Tetrahedron Lett. 1985, 26, 5997-6000. doi:10.1016/S0040-4039(00)95108-6

11. Copar, A.; Antoncic, L.; Antoncic, M. T. A Synthesis of 4-Bromomethyl-2'-Formylbiphenyl and 4-Bromomethyl-2'-Hydroxymethyl biphenyl and Its Use in Preparation of Angiotensin II Antagonists. Int. Pat. Appl. WO 2006/103068A1, 2006.

12. Reuman, M.; Meyers, A. I. Tetrahedron 1985, 41, 837-860. doi:10.1016/S0040-4020(01)96401-4

13. Goossen, L. J.; Knaubar, T. J. Org. Chem. 2008, 73, 8631-8634. doi:10.1021/j0801937h

\section{License and Terms}

This is an Open Access article under the terms of the Creative Commons Attribution License

(http://creativecommons.org/licenses/by/2.0), which permits unrestricted use, distribution, and reproduction in any medium, provided the original work is properly cited.

The license is subject to the Beilstein Journal of Organic Chemistry terms and conditions:

(http://www.beilstein-journals.org/bjoc)

The definitive version of this article is the electronic one which can be found at: doi: $10.3762 /$ bjoc. 6.25 